\title{
Birth Rates and the Vietnam Draft ${ }^{\otimes}$
}

\author{
Marianne Bitler \\ University of California at Irvine and NBER \\ Lucie Schmidt \\ Williams College
}

November 2011

The Vietnam conflict was the defining event for a generation, with nearly 8 million Americans serving in the armed forces. A large literature in economics has focused on effects of VietnamEra service post-war, while little research looks at contemporaneous effects of the mobilization, despite the potential for this mobilization to change marriage markets for particular cohorts. We use exogenous variation across states and over time in the share of men 19-25 drafted to look at the effects of the wartime mobilization on birth rates. We find robust evidence that higher rates of inducted men led to significantly lower birth rates.

\footnotetext{
${ }^{\otimes}$ We are grateful to Walter Komorowski for assistance in obtaining data, and to Melanie Guldi and Hilary Hoynes for sharing data. We are also grateful to Susan Averett, David Card, Mary Daly, Ron Lee, Marianne Page, and seminar participants at Williams College, Lafayette College, the Mt. Holyoke College Conference on Public Policy and the Economics of the Family, and the UC Berkeley Demography Brown Bag Series for helpful comments. Contact information: Department of Economics, Schapiro Hall, Williams College, Williamstown, MA 01267, email: lschmidt@williams.edu.
} 
During the Vietnam Conflict, over 8 million Americans served in the armed forces, and almost 3.5 million were deployed to Southeast Asia (Department of Veterans’ Affairs). The war is considered by some to be the defining event of that generation - not just because of the number of troops deployed (the largest since the Second World War), but because of how it affected all men of that generation - those who served, as well as those who were able to avoid service.

While a large literature has examined effects of the draft on post-war outcomes for veterans, effects of the war-time mobilization on family formation during the time of the conflict have been largely ignored. The mobilization led to the absence of a large number of young men from local marriage markets, and this shock to sex ratios could have significantly disrupted normal family formation patterns, including assortative matching and fertility behavior. ${ }^{1}$

In this paper, we exploit variation across states and over time on Vietnam-era inductions to analyze the effects of the wartime mobilization on these family formation patterns. Our results suggest that having a larger share of men aged 19-25 drafted led to a decrease in birth rates for women aged 15-30. These results are statistically significant, robust to a number of different specifications, and demographically meaningful in magnitude.

\section{Background}

\section{A. The Vietnam Conflict and the Draft}

\footnotetext{
${ }^{1}$ In addition, draft deferments for married men and men with dependents also affected family formation during certain early years of the war, primarily before our time period of interest (see discussion below).
} 
Over the course of the Vietnam Era, from 1965 through 1975, the Selective Service System was used to obtain draftees or inductees into the Armed Forces. Upon turning the age of 18, young men were required to register with their local draft boards. They were then classified by the local draft board as exempted, deferred, or available for service. Those who were classified as available for service (I-A) and who passed a pre-induction examination were then required to report for induction when notified.

During certain years of the conflict, a number of deferments were available to registrants. Paternity deferments were available until 1970 (Davis and Dolbeare, 1968). Between 1963 and 1965 married childless men were also able to get a deferment (Davis and Dolbeare, 1968; Kutinova, 2009). In addition, educational deferments meant that men who could afford to stay in college full time were able to delay, and in many cases, forgo service. Throughout most of the war, those working on a four-year degree were eligible for educational deferments as long as they remained in good standing, until they turned 24. College graduates could obtain graduate school deferments (issued until 1968), or occupational deferments (issued until 1970). New college deferments were not given after 1971, but those with an existing deferment could keep it.

As illustrated by Figure 1, inductions at the national level rose from fiscal year 1960 to fiscal year 1968, and then fell until the suspension of the draft in 1973, with a total of 2.25 million men being inducted over this time period. ${ }^{2}$ Most draftees were inducted into the Army and served for two years (Moskos, 1970). Draftees were assigned a particular type of advanced training and had little or no say in the matter. After finishing advanced training, service men

\footnotetext{
${ }^{2}$ The draft lottery used in much of the literature on veteran outcomes began in 1970, after inductions had already begun to fall. The majority of men drafted during the Vietnam conflict were drafted before the lottery started.
} 
would receive their first permanent duty assignment. Soldiers assigned to Vietnam after their training served in an individual rotation system with a twelve-month tour of duty in Vietnam (Moskos, 1970). The combination of time spent in training and the twelve-month tours of duty meant that most drafted soldiers were away from home for the majority of their two-year terms.

A large literature looks at post-war outcomes for Vietnam veterans, yet effects of the war-time mobilization on family formation at the time of the conflict has been largely ignored. ${ }^{3}$ The mobilization led to the absence of a large number of young men from local marriage markets, and as such could have significantly disrupted normal peacetime family formation patterns, including matching in marriage markets and fertility behavior.

\section{B. Likely Effects of Vietnam on Family Formation}

Becker (1981) discusses the critical role played by the sex ratio in family formation and the marriage market. Theory suggests that imbalanced sex ratios should affect marriage markets, fertility, and the share of births that are non-marital, as well bargaining power and division of marital surplus between partners. In addition, imbalanced sex ratios should affect assortative mating, with a decrease in the number of men in a market implying that remaining men will be able to mate with women of a higher quality or class than was previously possible (Becker, 1981; Burdett and Coles, 1997).

\footnotetext{
${ }^{3}$ Two notable exceptions are Bailey (2011) and Kutinova (2009). Bailey examines the use of marriage and paternity deferments as a draft avoidance strategy, and finds availability of deferments is associated with increases in birth rates during the years 1966-1970. Kutinova examines the effects of paternity deferments issued in the early years of the Vietnam conflict, and finds that the strong incentives to have a first child significantly affected fertility timing among US couples.
} 
A large empirical literature tests for these effects of sex ratios on a number of outcomes, exploiting plausibly exogenous variation in sex ratios by using data on immigration policy (Angrist, 2002), incarceration rates (Charles and Luoh, 2010) and war-related male mortality -in France during WWI (Abramitzky et al., 2011), in Russia during WWII (Brainerd, 2008), and in Bavaria in WWII (Kvasnicka and Bethmann, 2009). These papers find that regions with more women per man experience decreases in marriage and fertility, increases in out-of-wedlock childbearing, and improvements in men’s marriage matches. ${ }^{4}$ This empirical literature also shows that marriage markets are defined quite narrowly by race, age, and geographic location.

The Vietnam-era mobilization could have had similar effects on family formation patterns. Servicemen were tightly concentrated in specific age ranges, and induction rates for men 19-25 ranged as high as nine per 100 men in some states over our time period of interest1969-1979. As described above, Vietnam-era draftees generally served two year terms, with a one-year tour of duty in Vietnam. However, the constant rotation of young men in and out of Vietnam could have led to serious disruptions in normal family formation patterns. Women may have been less likely to marry and have children. If they did marry or have children, we might expect the matches they made to be "worse" in some sense. However, not all effects would necessarily have been negative. Women may have been more likely to stay in school, and delays in marriage and childbearing could have led to better matches and greater labor force attachment. In this paper, we seek to examine the effect of the Vietnam-era mobilization on birth rates. We do so by exploiting variation in inductions by state and year. In Bitler and Schmidt (2011), we show that there was considerable variation across states and regions in the rate of

\footnotetext{
${ }^{4}$ Related work by Larsen et al. (2011) examines the effect of education induced by the G.I. Bill on marital quality for men.
} 
inductions, as well as in how these rates changed over time. This variation across states and over time was generated by the three-tier Selective Service System. Federal policies regarding the draft were issued to the states, which then interpreted them and passed information on to the local draft boards. There were a number of differences in state-level interpretations of federal policies. In addition, there was a significant degree of idiosyncratic discretionary decisionmaking by local boards, such that jurisdictions with similar socioeconomic characteristics ended up with largely varying shares of registrants who were deferred or exempted. ${ }^{5}$ Using the 1980 Census, we regress an indicator for veteran status on the induction rate, and find that our measure of induction risk is shown to be significantly associated with Vietnam veteran status for the overall population of men, as well as for high school dropouts and high school graduates. We find no effect for college graduates, which is what we would expect given educational differentials in service (e.g., Card and Lemieux, 2001).

\section{Methodology, data, and results}

We obtain data on the number of inductions of Selective Service Registrants to meet requisitions of the Armed Forces for each state and year. Draftees served two-year terms, so we calculate estimates of the draftees who were away from home by summing the inductions for the current fiscal year and one year lagged (so, our number of draftees for 1969 is equal to the sum of those inducted in 1968 and 1969). We set inductions equal to zero for all years 1974 and later. We calculate denominators for the share of men age 19-25 who were drafted using population data from the Surveillance Epidemiology and End Results database.

\footnotetext{
${ }^{5}$ In Bitler and Schmidt (2011), we examine the determinants of inductions per 100 men aged 1925 as a function of various covariates during the years while the draft was in effect. We control for these covariates in our regressions of the effect of the induction rate on birth rates here.
} 
Our data on births come from Vital Statistics Detail Natality Data (DND), gathered by the National Center for Health Statistics. We use the DND data from 1969-1979. ${ }^{6}$ Using the DND, we calculate birth counts by single year of age of the mother, race of the mother, month of birth, and mother's state of residence. We use the SEER population data described above to calculate denominators to transform our birth counts into birth rates (per 1000 women).

We estimate regressions for women aged 15-30. The dependent variable is the natural log of the birth rate. Our key independent variable is the average of the share of men drafted in the past two years, merged in by the year of conception. We also control for whether abortion was legal during the first trimester of the pregnancy, and for other policy and economic variables that existing literature suggests will affect birth rates over this time period, including welfare generosity and state labor market conditions for the state and conception year. In addition to fixed effects for single year of age of the woman and race (where relevant), we control for state of residence and year and month of infant's birth fixed effects or, in some specifications, year by month or year of conception and month fixed effects. We weight regressions to be populationrepresentative and we present robust standard errors clustered at the state level.

Our results suggest that the share of men 19-25 drafted this year or last year is negatively and statistically associated with the birth rate for women 15-30. The estimate of $\beta 1$ ranges from -0.016 to -0.020 , and is statistically significant at between the $1 \%$ and $5 \%$ level, depending on

\footnotetext{
${ }^{6}$ Since our birth data begin in 1969, we only exploit the decrease in induction rates that occurred in the late 1960s and early 1970s, and do not examine the preceding increase in induction rates that began in the early 1960s. In addition, we are unable to examine the effects of the marriage and paternity deferments which had mostly ended by the time our data begin. Evidence suggests that these deferments had a positive effect on fertility (Bailey (2011), Kutinova (2009)).
} 
the model. Our preferred estimate includes all control variables and state, year, and month of birth fixed effects, and suggests that an increase of 1 man drafted in a state per 100 men aged 1925 leads to a 1.6 percent decrease in the birth rate. Since the average birth rate for women 15-30 is 8.8 per 1000 women, one additional man being drafted means about 0.3 fewer births per 1000 women. The magnitude of this effect implies that the actual decrease in the draft rate from 19691974 led to an increase in the birth rate of between 3.9 and 4.7 percent.

\section{Discussion and Conclusion}

In this paper, we present a preliminary look at the effects of Vietnam-era inductions of men into the armed forces on family formation. We find robust evidence that higher rates of inducted men led to significantly lower birth rates. Our results are consistent with theoretical models of sex ratio effects, as well as with the related empirical literature. In ongoing work, we are examining how the relationship between inductions and birth rates varies by the age of the mother as well as by the reported age of the father. We are also examining effects on marriage. Finally, we are looking to more recent data to see if this reduction in births had long-run effects on women's fertility timing and on completed fertility.

\section{References}

Abramitzky, R., A. Delavande, and L. Vasconcelos. 2011. “Marrying Up: The Role of Sex Ratio in Assortative Matching.” American Economic Journal: Applied Economics 3(3): 124-57. Angrist, J. 2002. “How Do Sex Ratios Affect Marriage and Labor Markets? Evidence from America’s Second Generation.” Quarterly Journal of Economics.

Bailey, M. J. 2011. "How America Avoided the Draft: The Demographic Legacy of Vietnam.” Mimeo. 
Bailey, M. J. 2006. “More Power to the Pill: The Impact of Contraceptive Freedom on Women’s Life Cycle Labor Supply.” Quarterly Journal of Economics 12: 289-320.

Becker, G. S. 1981. A Treatise on the Family. Cambridge, MA: Harvard University Press.

Bitler, M. and L. Schmidt. 2011. "Marriage Markets and Family Formation: The Role of the Vietnam Draft.” Mimeo.

Brainerd, E. 2008. "Uncounted Costs of WWII: The Effect of Changing Sex Ratios on Marriage and Fertility of Russian Women.” Mimeo.

Burdett, K. and M. G. Coles. 1997. “Marriage and Class.” Quarterly Journal of Economics 112 (1), 141-168.

Card, D. and T. Lemieux. 2001. “Going to College to Avoid the Draft: The Unintended Legacy of the Vietnam War.” AER Papers and Proceedings 91: 97-102.

Charles, K. K. and M-C. Luoh. 2010. "Male Incarceration, the Marriage Market, and Female Outcomes.” Review of Economics and Statistics 92(3): 614-22.

Davis, J. W. Jr and K. M. Dolbeare. 1968. Little Groups of Neighbors: The Selective Service System. Westport, CT: Greenwood Press.

Guldi, M. 2008. "Fertility Effects of Abortion and Birth Control Pill Access for Minors.” Demography 45(4): 817-27.

Kvasnicka, M. and D. Bethmann. 2009. World War II, Missing Men, and Out-of-Wedlock Childbearing. Mimeo.

Kutinova, A. 2009. "Paternity Deferments and the Timing of Births: U.S. Natality During the Vietnam War.” Economic Inquiry 47(2): 351-65.

Larsen, M., T. J. McCarthy, J. Moulton, M. Page, and A. Patel. 2011. "War and Marriage: Assortative Mating and the World War II G.I. Bill. Mimeo. 
Moskos, C. C. Jr. 1970. The American Enlisted Man: The Rank and File in Today’s Military. New York: Russell Sage Foundation. 
Figure 1: Total inductions by year, 1960-1979

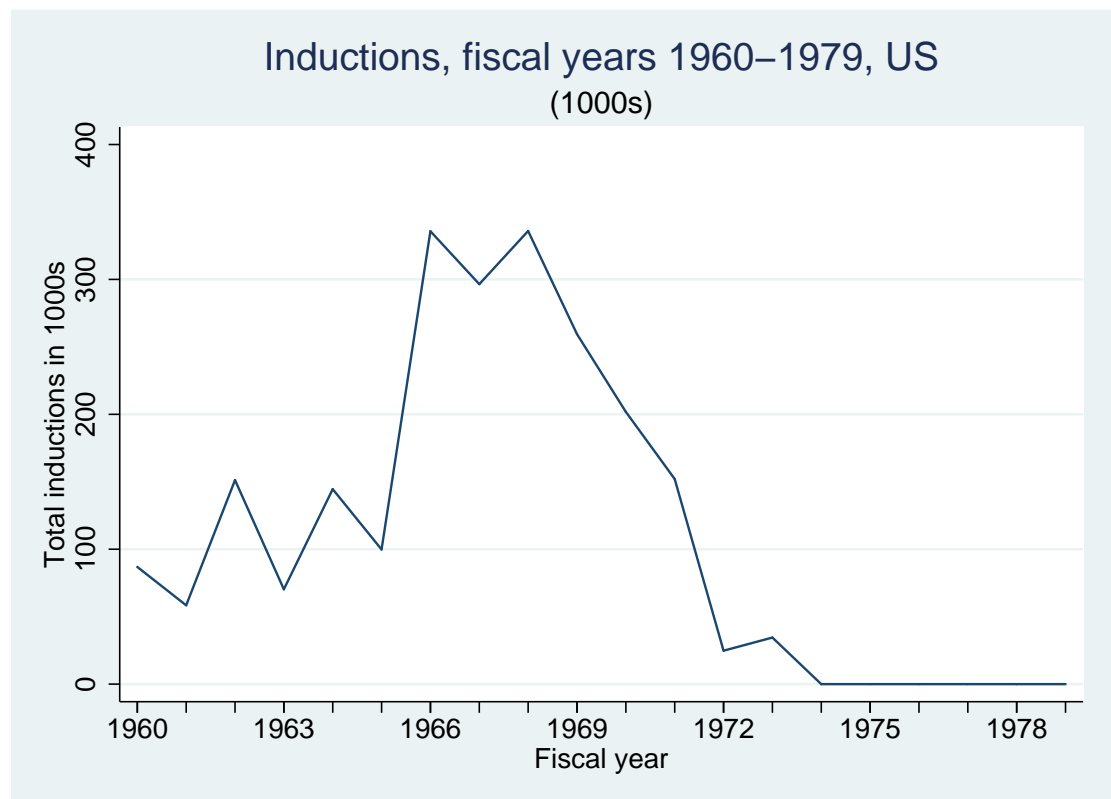

